\title{
Ketahanan Batang Kelapa Sawit Diimpregnasi Resin Pinus dan Serbuk Kayu Surian Terhadap Rayap dan Cuaca
}

\author{
Jessica Gita Adjani, Anne Hadiyane*, Tati Karliati, Atmawi Darwis, Viona Febrinisa Mukhsin \\ Sekolah Ilmu dan Teknologi Hayati , Institut Teknologi Bandung, Jl. Ganesha 10, Bandung, Indonesia \\ Diterima : 22 September 2021, Revisi akhir : 16 Desember 2021, Disetujui terbit : 30 Desember 2021

\section{The Resistance of Pine Resin and Surian Wood Sawdust Impregnated Oil Palm Stem Against Termite and Weathering}

\begin{abstract}
Impregnation substances into the oil palm trunks are one way to improve the oil palm trunk quality. This paper studies the optimum formulation of oil palm trunk impregnanted pine resin and Surian sawdust against dry-wood and subterranean termites as well as weathering performance. Impregnant concentration variations were mixtures of Tusam resin and Surian wood sawdust of 0\% (RSO), 4\% (RS1), 6\% (RS2), and 8\% (RS3) with three replications. Dry-wood termite test, subterranean termite test, and weather resistance test were carried out for 12 weeks of observation. The results showed that RS3 treatments were the optimum formulation of impregnated material used for oil palm trunk based on its resistance against dry-wood and subterranean termites resistance, while RSO treatments were the optimum formula for weathering performances.
\end{abstract}

Keywords: impregnation, oil palm trunk, pine resin, sawdust, Surian wood

\begin{abstract}
Abstrak
Salah satu upaya untuk meningkatkan kualitas batang kelapa sawit adalah melalui impregnasi dengan resin pinus dan serbuk kayu Surian. Penelitian ini bertujuan untuk menentukan formulasi optimum impregnan batang kelapa sawit terhadap serangan rayap kayu kering dan rayap tanah serta ketahanan terhadap cuaca. Variasi konsentrasi impregnan yang digunakan yaitu campuran resin pinus dan serbuk kayu Surian 0\% (RS0), 4\% (RS1), 6\% (RS2), dan 8\% (RS3). Uji ketahanan rayap kayu kering, uji rayap tanah, dan uji ketahanan terhadap cuaca dilakukan selama 12 minggu pengamatan. Hasil penelitian menunjukkan bahwa konsentrasi optimum bahan impregnan batang kelapa sawit terimpregnasi terhadap ketahanan rayap kayu kering dan rayap tanah adalah formula RS3, sedangkan formulasi impregnan ketahanan cuaca optimum adalah batang kelapa sawit dengan formula RS0.
\end{abstract}

Kata kunci: impregnasi, batang kelapa sawit, resin pinus, serbuk kayu, kayu Surian 


\section{Pendahuluan}

Indonesia memiliki perkebunan kelapa sawit yang cukup luas. Berdasarkan Tabel 1, dapat dilihat bahwa perkembangan luas areal kelapa sawit dari 2017-2021 cukup pesat. Luas areal perkebunan kelapa sawit tersebar di 26 provinsi di Indonesia dengan 6 provinsi di Indonesia dengan luas areal di atas 1 juta $\mathrm{Ha}$ antara lain Provinsi Riau, Sumatera Utara, Kalimantan Barat, Kalimantan Tengah, Sumatera Selatan, dan Kalimantan Timur pada tahun 2017. Provinsi Riau adalah provinsi yang memiliki areal perkebunan kelapa sawit yang paling luas, dari tahun 2017-2019 memiliki luas lebih dari 2,7 juta Ha (Kementerian Pertanian, 2020).

Tabel 1. Luas area kelapa sawit tahun 2017-2021

\begin{tabular}{cc}
\hline Tahun & Luas Area $(\mathrm{Ha})$ \\
\hline 2017 & 14.048 .722 \\
2018 & 14.326 .350 \\
2019 & 14.456 .611 \\
2020 & $14.858 .300^{\text {(angka sementara) }}$ \\
2021 & $15.081 .021^{\text {(angka estimasi) }}$ \\
\hline
\end{tabular}

Sumber : Direktorat Jenderal Perkebunan (2020)

Peremajaan areal kelapa sawit merupakan proses penggantian pohon kelapa sawit tua (berumur 20-25 tahun) dengan kelapa sawit muda. Proses peremajaan ini untuk membuat produktivitas pohon kelapa sawit tetap tinggi serta kuantitas dan kualitas dari kelapa sawit tetap terjaga. Pemerintah menargetkan Program Peremajaan Sawit Rakyat (PSR) dari tahun 2020-2022 dapat terealisasi sebesar 540 ribu ha yang tersebar di berbagai wilayah di Indonesia, diantaranya wilayah Sumatera sebanyak 397.200 ha, Jawa 6.000 ha, Kalimantan 86.300 ha, Sulawesi 44.500 ha, dan Papua 600 ha (Kementerian Koordinator Bidang Perekonomian, 2021). Kayu gergajian yang dihasilkan dari peremajaan sebesar $50,1 \mathrm{~m}^{3} /$ ha dari $1 / 3$ bagian tepi batang kelapa sawit yang keras, sedangkan $2 / 3$ batang kelapa sawit yang lunak menjadi limbah (Hartono and Erwinsyah, 2018). Apabila limbah batang kelapa sawit termanfaatkan, akan membawa dampak positif bagi pengelola perkebunan dan bagi industri yang menggunakan bahan baku dari kayu sehingga pengelolaan perkebunan akan mengarah pada konsep zero waste. Oleh karena itu, batang kelapa sawit memiliki potensi yang sangat besar sebagai alternatif pengganti kayu.
Kelapa sawit (Elaeis guineensis Jacq) merupakan tumbuhan tropis yang berasal dari Nigeria. Kelapa sawit termasuk dalam golongan famili Palmaceae, sub-family Palminanae, dengan genus Elaeis. Kelapa sawit termasuk tumbuhan pohon yang berkembang biak dengan biji, tinggi pohon dapat mencapai $24 \mathrm{~m}$. Batang kelapa sawit pada dasarnya bahan berkayu yang memiliki struktur yang relatif tidak seragam dan memiliki kesan struktur yang seperti batang kelapa dengan konfigurasi serat yang lebih pendek (Balfas, 2003).

Pemanfaatan batang kelapa sawit selama ini masih belum dilakukan secara komersial dan maksimal. Hal ini dikarenakan memiliki kendala pada sifatnya. Kelemahan pada batang kelapa sawit yaitu memiliki kadar air yang cukup tinggi, kerapatan yang cukup rendah, kelas kuat yang bervariasi dari kelas III-V, serta keawetan yang sangat rendah (Hartono and Erwinsyah, 2018). Selain itu, batang kelapa sawit memiliki kelemahan stabilitas dimensi dan sifat penggergajian (Mulyono, 2000). Oleh karena itu, perlu dilakukan peningkatan sifatsifat batang kelapa sawit, salah satu diantaranya dengan impregnasi. Impregnasi adalah upaya perbaikan kualitas kayu dengan memasukkan bahan pengisi (filler) melalui bantuan tekanan dalam tangki tertutup. Penelitian yang dilakukan oleh Erwinsyah (2008) adalah dengan melakukan perlakuan impregnasi batang kelapa sawit menggunakan bioresin dapat meningkatkan sifat fisik, mekanis, serta sifat pemesinan dari batang kelapa sawit. Menurut Nurfajriani (2015), proses impregnasi adalah proses penggantian posisi (replacement) dengan cara mengisi kayu dengan resin yang akan membantu larutan dengan molekul yang berukuran cukup kecil yang menembus dinding sel. Penggunaan resin pinus sebagai bahan impregnan telah banyak dilakukan dan berpengaruh terhadap peningkatan kualitas dan sifat dari batang kelapa sawit. Penelitian menunjukkan bahwa penggunaan resin getah Pinus merkusii sebagai bahan impregnan dapat meningkatkan kelas kuat batang kelapa sawit (Sukatik and Yunida, 2006). Selain itu, resin yang digunakan dalam kedua penelitian tersebut merupakan resin dari alam yang belum dilakukan pengolahan lebih lanjut sehingga ramah lingkungan, aman bagi manusia, serta mudah didapatkan. Oleh karena itu, penelitian ini bertujuan untuk menentukan konsentrasi optimum batang kelapa sawit terimpregnasi 
dengan impregnan berbahan resin pinus (Pinus merkusii) dan serbuk kayu Surian (Toona sinensis) terhadap ketahanan serangan rayap kayu kering dan rayap tanah serta cuaca.

\section{Bahan dan Metode}

\section{Alat dan Bahan}

Alat yang digunakan pada penelitian ini adalah alat impregnasi, ayakan (120 dan 230 mesh), baki, batang pengaduk, chromameter, corong, desikator, Erlenmeyer $(250 \mathrm{~mL}$ dan 500 $\mathrm{mL}$ ), FT-IR Prestige 21 Shimidzu, gelas kimia 1 L, kaliper, oven, penangas, penggaris, dan spatula.Bahan yang digunakan dalam penelitian ini adalah kayu batang kelapa sawit yang diperoleh dari Hutan Rakyat Bogor, resin pinus dari Arboretum Boscha, serbuk kayu surian dari Hutan Rakyat Cibugel di Kabupaten Sumedang, metanol, plastisin, dan kertas saring.

\section{Metode}

Desain eksperimen yang digunakan dalam penelitian ini adalah Rancangan Acak Lengkap (RAL). Metode penelitian yang digunakan yaitu metode eksperimental teknologi impregnasi dengan penggunaan impregnan yaitu campuran resin pinus dan serbuk kayu surian (resin-serbuk) yang akan dibandingkan dengan tanpa formulasi impregnasi (kontrol). Variasi konsentrasi impregnan yang digunakan untuk masing-masing formulasi ada 4 yaitu campuran resin pinus dan serbuk kayu surian 0\% (RS0), 4\% (RS1), $6 \%$ (RS2), dan 8\% (RS3). Kontrol dan variasi formulasi dilakukan 3 ulangan.

\section{Persiapan Sampel Uji}

Batang kelapa sawit dikeringkan hingga mencapai kadar air 15\% kering udara. Dimensi batang sawit disesuaikan dengan SNI 7207:2014 Uji ketahanan kayu terhadap organisme perusak kayu dan ASTM D1435-99 - Standard Practice for Outdoor Weathering of Plastics (Islam et al., 2013). Batang kelapa sawit yang digunakan bagian antar dalam (inner) menuju bagian tengah (center) dengan kerapatan 0,30-0,35 $\mathrm{g} / \mathrm{cm}^{3}$. Setelah itu, batang kelapa sawit (sampel) dibagi menjadi 3 bagian dengan 1 bagian untuk tanpa perlakun (kontrol) dan 2 bagian lainnya untuk formulasi campuran ekstrak kayu dan resin pinus serta campuran resin pinus dan serbuk kayu surian.

\section{Pembuatan Larutan Impregnasi Resin Pinus dan Serbuk Kayu Surian}

Resin pinus dicampurkan dalam metanol dengan konsentrasi $10 \% \quad \mathrm{w} / \mathrm{v}$ menggunakan magnetic stirrer. Setelah itu, serbuk surian hasil ekstraksi yang telah dikeringkan serta disamakan ukuran menggunakan ayakan 230 mesh. Penentuan konsentrasi pencampuran berdasarkan penelitian Basri dan Balfas (2014). Serbuk kayu surian kemudian dicampur dalam larutan resin pinus dengan konsentrasi $0 \%$ (resin pinus/RS0), 4\% (RS1), 6\% (RS2), dan 8\% (RS3) $\mathrm{w} / \mathrm{v}$ masing-masing 2 liter menggunakan mixer.

\section{Impregnasi Vakum-Tekan Sampel Uji}

Metode impregnasi batang kelapa sawit berdasarkan penelitian yang dilakukan oleh Basri dan Balfas (Basri and Balfas, 2014). Sampel di masukkan ke dalam alat impregnasi. Kemudian, divakum pada tekanan $30 \mathrm{MPa}$ selama 15 menit. Setelah itu, larutan impregnan dimasukkan ke dalam alat impregnasi. Setelah sampel dan larutan impregnan dimasukkan ke dalam alat, untuk membantu masuknya impregnan ke dalam sampel kayu sawit, alat dioperasikan dengan tekanan 7,5 $\mathrm{kgf} / \mathrm{cm}^{2}$ selama 1,5 jam. Khusus untuk larutan impregan serbuk kayu surian dengan resin pinus dimasukkan sambil di-mixer supaya tercampur merata. Setelah itu, tekanan dalam alat impregnasi diturunkan dan larutan impregnan dikeluarkan dalam tabung lalu ditiriskan selama 10 menit dan dilakukan penimbangan. Kemudian, dilakukan proses curing dengan membungkus sampel menggunakan aluminium foil lalu dioven hingga mencapai kadar air sekitar 10\%. Kemudian dilakukan penimbangan dan pengukuran dimensi.

\section{Parameter Uji}

\section{Uji Rayap Kayu Kering}

Pengujian rayap kayu kering menggunakan metode SNI 7207:2014 - Uji ketahanan kayu terhadap organisme perusak kayu. Sampel dikeringtanurkan dengan cara dioven pada suhu $103 \pm 2^{\circ} \mathrm{C}$ selama 2 jam. Sampel ditimbang $\left(W_{l}\right)$ sebelum diuji. Setelah itu, sampel direkatkan dengan pipa paralon berdiameter $1 / 2$ inci dan 
tinggi $5 \mathrm{~cm}$ menggunakan palstisin. Sebanyak 50 ekor rayap dimasukkan ke dalam pipa paralon dan ditutup menggunakan kapas. Sampel disimpan selama 12 minggu atau 3 bulan di ruang gelap. Setelah 3 bulan, sampel dibersihkan dari rayap serta dihitung jumlah rayap mati untuk mengetahui mortalitas rayap menggunakan Persamaan 1. Setelah itu, sampel dikeringtanurkan menggunakan oven pada suhu $103 \pm 2^{\circ} \mathrm{C}$ selama 2 jam dan ditimbang $\left(W_{2}\right)$ untuk mengetahui penurunan berat menggunakan Persamaan 2. Penentuan kelas awet sampel yang telah diuji, mengacu pada SNI 7207:2014 - Uji ketahanan kayu terhadap organisme perusak kayu (Tabel 2).

$$
\begin{aligned}
& M R=\frac{D}{50} \times 100 \% \\
& P=\frac{W_{1}-W_{2}}{W_{1}} \times 100 \%
\end{aligned}
$$

Keterangan :

$M R$ adalah mortalitas rayap

$D$ adalah jumlah rayap mati

$P$ adalah penurunan berat

$W$, adalah berat sebelum dioven

$W_{2}$ adalah berat setelah dioven

Tabel 2. Kelas awet terhadap rayap kayu kering

\begin{tabular}{clc}
\hline Kelas & \multicolumn{1}{c}{ Ketahanan } & $\begin{array}{c}\text { Penurunan berat } \\
(\%)\end{array}$ \\
\hline I & Sangat tahan & $<2,0$ \\
II & Tahan & $2,0-4,3$ \\
III & Sedang & $4,4-8,1$ \\
IV & Tidak tahan & $8,2-28,1$ \\
V & Sangat tidak tahan & $>28,1$ \\
\hline
\end{tabular}

Sumber: SNI 7207:2014

\section{Uji Rayap Tanah}

Pengujian ini mengacu pada penelitian Verinita (2012). Persiapkan lahan uji dengan menggali lahan dengan kedalaman $15 \mathrm{~cm}$ pada titik peletakkan sampel serta diberi jarak antar titik $30 \mathrm{~cm}$ dan antar baris $60 \mathrm{~cm}$ (Gambar 1). Apabila tanah keras karena musim kemarau dapat dilakukan persiapan lahan dengan cara menyiram lahan agar lembab. Sampel uji dikering tanurkan dioven pada suhu $103 \pm 2^{\circ} \mathrm{C}$ selama 2 jam lalu timbang $\left(W_{1}\right)$ sebelum uji kubur. Sampel dikubur secara acak dan dibiarkan selama 3 bulan.
Setelah 3 bulan, sampel dibersihkan dari rayap dan dikering tanurkan menggunakan oven pada suhu $103 \pm 2^{\circ} \mathrm{C}$ selama 2 jam lalu timbang $\left(W_{2}\right)$ untuk mengetahui penurunan berat menggunakan Persamaan 2. Penentuan kelas awet sampel yang telah diuji, mengacu pada SNI 7207:2014 - Uji ketahanan kayu terhadap organisme perusak kayu (Tabel 3). Setelah itu dilakukan pengamatan derajat kerusakan dengan ketentuan pada Tabel 4.

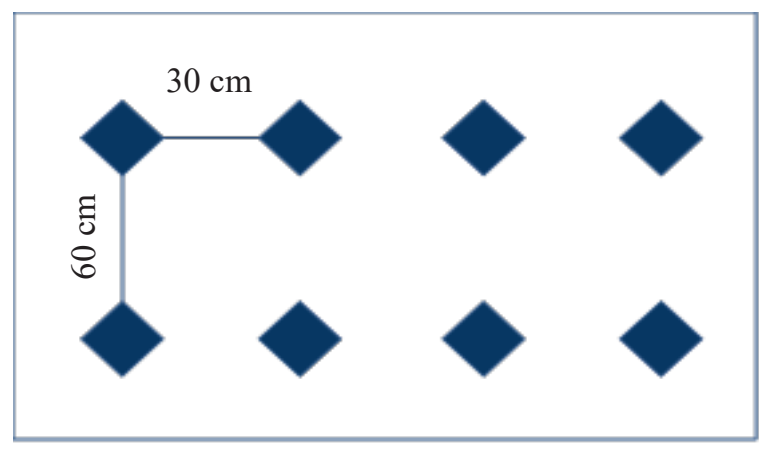

Gambar 1. Skema pengujian rayap tanah

Tabel 3. Kelas awet terhadap rayap tanah

\begin{tabular}{clc}
\hline Kelas & Ketahanan & $\begin{array}{c}\text { Penurunan berat } \\
(\%)\end{array}$ \\
\hline I & Sangat tahan & $<3,5$ \\
II & Tahan & $3,5-7,4$ \\
III & Sedang & $7,5-10,8$ \\
IV & Tidak tahan & $10,9-18,9$ \\
V & Sangat tidak tahan & $>18,9$ \\
\hline Sumber: SNI 7207:2014
\end{tabular}

Tabel 4. Derajat kerusakan terhadap rayap tanah

\begin{tabular}{lc}
\hline \multicolumn{1}{c}{ Derajat Kerusakan } & Nilai \\
\hline Utuh atau serangan sangat ringan (0\%-5\%) & 0 \\
Serangan ringan $(6 \%-15 \%)$ & 40 \\
Serangan sedang $(16 \%-30 \%)$ & 70 \\
Serangan berat $(31 \%-50 \%)$ & 90 \\
Serangan sangat berat $(>50 \%)$ & 100 \\
\hline
\end{tabular}

Sumber: SNI 7207:2014

\section{Uji Cuaca}

Pengujian cuaca mengacu pada ASTM D143599 - Standard Practice for Outdoor Weathering of Plastics yang digunakan dalam penelitian Islam et al. (2013). Pengujian Fourier Trasform Infra Red (FT-IR) dilakukan setiap bulan. Sampel untuk uji FT-IR, dipotong $1 \mathrm{~cm}$ kemudian 
timbang dan diukur dimensi. Setelah itu, sampel didokumentasikan bagian depan dan belakang serta dilakukan pengujian warna menggunakan chromameter sebelum disimpan. Sampel disimpan di ruangan terbuka selama 3 bulan. Setelah 3 bulan dilakukan pengujian warna. Parameter yang diuji adalah penurunan berat menggunakan Persamaan 2, total perubahan warna $(\Delta \mathrm{E} / \mathrm{dE})$ menggunakan Persamaan 3 (Krisdianto, Satiti and Supriadi, 2018), serta analisis hasil FT-IR.

$$
\Delta E=\sqrt{\Delta L^{2}+\Delta a^{2}+\Delta b^{2}}
$$

Keterangan :

$\Delta L$ adalah perubahan kecerahan

$\Delta a$ adalah perubahan merah-hijau

$\Delta b$ adalah perubahan kuning-biru

\section{Analisis Data}

Penelitian ini menggunakan metode Rancangan Acak Lengkap (RAL) dengan satu faktor. Data yang diperoleh dilakukan analisis dengan menggunakan analisis sidik ragam atau One Way ANOVA pada tingkat signifikansi $(\alpha)$ 0,05 atau tingkat kepercayaan $95 \%$. Uji statistik lanjut menggunakan DMRT (Duncan Multiple Range Test) untuk formulasi berbeda nyata.

\section{Hasil dan Pembahasan}

\section{Ketahanan Rayap Kayu Kering}

Mortalitas merupakan salah satu parameter untuk menilai kemampuan dari bahan pengawet atau bahan impregnan terhadap serangan rayap. Menurut Verinita (2012), mortalitas merupakan persentase dari jumlah rayap yang mati selama pengujian. Gambar 2 menunjukkan bahwa kayu sawit yang diimpregnasi dengan resin pinus dan serbuk kayu surian dapat meningkatkan nilai mortalitas rayap kayu kering. Pemberian resin pinus (RS0) dapat meningkatkan mortalitas dari rayap kayu kering. Penambahan konsentrasi serbuk kayu surian tidak terlihat perubahannya karena mortalitas dari RS1-RS3 tidak memberikan nilai yang berbeda.

Berdasarkan hasil uji ANOVA $(\alpha=0,05)$ menunjukkan perbedaan yang signifikan dari formulasi terhadap kontrol. Hasil uji DMRT menunjukkan tidak terdapat perbedaan yang signifikan dari formulasi resin-serbuk yang diberikan. Hal tersebut membuktikan bahwa penambahan konsentrasi serbuk surian tidak berpengaruh terhadap mortalitas rayap kayu kering. Kandungan zat ekstraktif pada kayu surian antara lain surenon, surenin, dan surenolakton yang memiliki fungsi insektisida, antifeedant (menghambat daya makan) bagi larva serangga uji ulat sutera dan repellant (pengusir) serangga (Rakhman, 2012). Diduga serbuk kayu surian yang digunakan tidak mengandung surenin, surenon dan surenolakton yang berperan sebagai antifeedant dan repellent pada serangga sehingga yang terdapat pada serbuk kayu surian hanya selulosa sebagai sumber makanan rayap kayu kering.

Gambar 2 menunjukkan pemberian resin pinus memiliki pengaruh terhadap peningkatan mortalitas rayap kayu kering. Menurut Dungani et al. (2013), resin mungkin tidak menjadi racun bagi rayap karena rayap mati ketika tidak dapat mencerna sampel yang terimpregnasi oleh resin. Hal tersebut dikarenakan batang kelapa sawit yang terimpregnasi akan memiliki kekerasan yang tidak dapat dicerna oleh rayap yang menyebabkan rayap mati. Menurut Verinita (2012), penyebab kematian rayap dalam pengujian ini rayap tidak diberikan variasi sumber makanan (no choice) sehingga rayap terpaksa memakan sumber makanan yang ada. Apabila sumber makanan tersebut tidak cocok dengan rayap, rayap memiliki kecenderungan kanibalisme. Proses kanibalisme yang terjadi adalah rayap yang sehat memakan rayap yang lemah.

Penurunan berat merupakan parameter lainnya dari pengujian rayap kayu kering. Menurut Verinita (2012), parameter kehilangan berat memiliki tujuan untuk mengetahui pengaruh jenis kayu, metode pengawetan, dan konsentrasi bahan

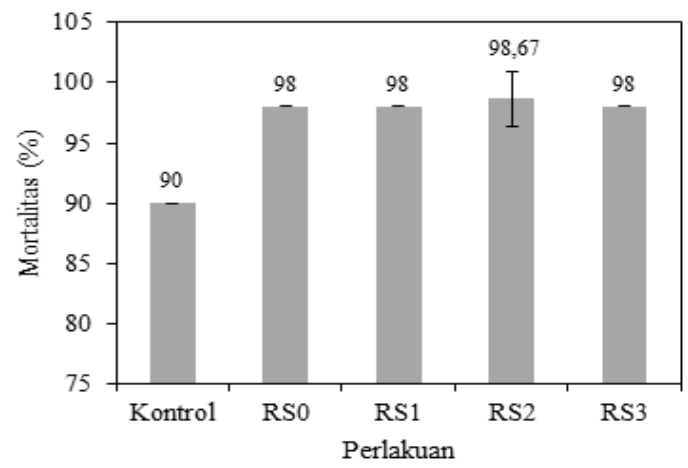

Keterangan :

RS0 = Resin; RS1 = Resin+4\% Serbuk;

RS2 $=$ Resin $+6 \%$ Serbuk; RS3 $=$ Resin $+8 \%$ Serbuk

Gambar 2. Mortalitas rayap kayu kering formulasi resin pinus dan serbuk kayu surian 
pengawet terhadap serangan rayap. Gambar 3 menunjukkan bahwa setiap kayu sawit yang diberi formulasi memiliki penurunan berat lebih rendah dibandingkan dengan kontrol. Penurunan berat dari yang paling rendah ke paling tinggi berturut-turut adalah RS2, RS1, RS3, RS0 dan kontrol.

Berdasarkan hasil uji ANOVA $(\alpha=0,05)$ menunjukkan perbedaan yang signifikan dari formulasi terhadap kontrol. Hasil uji DMRT menunjukkan tidak terdapat perbedaan yang signifikan antara formulasi RS1 dan RS3. Tabel 2 menunjukkan bahwa kontrol termasuk ke dalam kelas awet IV; RS0 dan RS3 kelas awet II; serta formulasi RS1 dan RS2 termasuk ke dalam kelas awet I. Ketahanan terhadap serangan rayap kayu kering pada sampel yang diberi formulasi dibandingkan dengan kontrol memiliki peningkatan berkisar 66\%-84\%. Peningkatan ketahanan untuk formulasi RS0 sebesar 68\%, RS1 77\%, RS2 84\%, dan RS3 75\%.

Penurunan berat pada formulasi resin dan serbuk kayu surian terjadi akibat lapisan serbuk pada permukaan batang kelapa sawit dikonsumsi oleh rayap kayu kering terlebih dahulu baru menyerang batang kelapa sawit. Hal tersebut dapat dibuktikan pada Gambar 4. Serbuk kayu surian yang digunakan memiliki kandungan selulosa dan sedikit zat ekstraktif. Kandungan zat ekstraktif yang sedikit diduga tidak akan meracuni rayap kayu kering sehingga rayap masih dapat menyerang batang kelapa sawit yang diberikan. Hal ini sesuai dengan pernyataan Dungani et al. (2013) bahwa rayap menggunakan selulosa pada kayu sebagai sumber makanan. Selain itu, kelas awet kayu sawit terhadap serangan rayap kayu

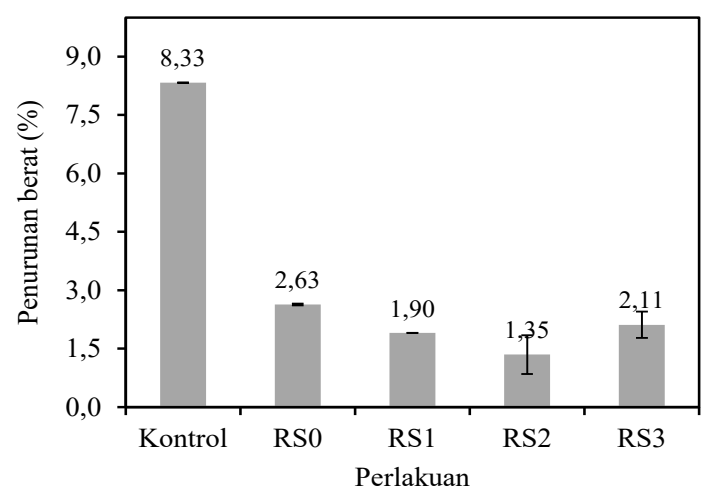

Keterangan : RS0 $=$ Resin; RS1 $=$ Resin $+4 \%$ Serbuk; RS2 $=$ Resin $+6 \%$ Serbuk; RS3 $=$ Resin $+8 \%$ Serbuk

Gambar 3. Penurunan berat rayap kayu kering formulasi resin pinus dan serbuk kayu surian sesuai dengan hasil penelitian yang dilakuan Dungani et al. (2013) yaitu memiliki kelas kuat IV.

\section{Ketahanan Rayap Tanah}

Pengujian ketahanan terhadap rayap tanah dilakukan di Arboretum Institut Teknologi Bandung, Kampus Jatinangor. Berdasarkan penelitian yang dilakukan oleh Dungani (2015) menunjukkan bahwa terdapat 4 spesies rayap tanah yang ada di wilayah tersebut. Spesies rayap tanah tersebut antara lain Macrotermes gilvus (Termitidae), Nasutitermes javanicus (Nasutitermitidae), Odontotermes javanicus (Termitidae) dan Schedorhinotermes javanicus (Rhinotermitidae). Hasil pengujian yang dilakukan selama 3 bulan untuk parameter penurunan berat dapat dilihat pada Gambar 5. Gambar 5 menunjukkan bahwa formulasi RS3 memiliki mortalitas yang paling rendah dibandingkan formulasi lainnya. Formulasi lainnya dari paling rendah ke paling tinggi berturut-turut adalah RS2, RS1, kontrol, dan RS0.

Berdasarkan hasil uji ANOVA $(\alpha=0,05)$ menunjukkan perbedaan yang signifikan dari

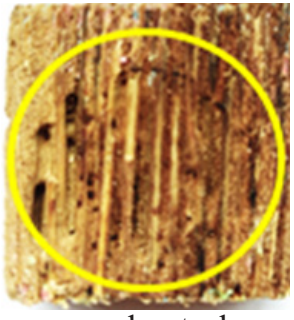

kontrol

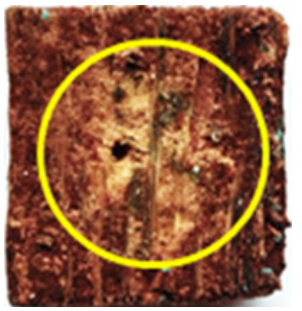

RS1

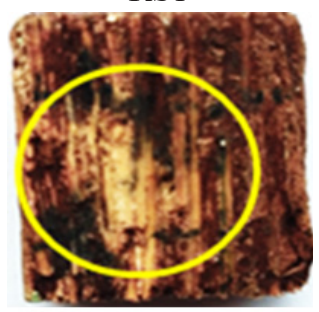

RS3

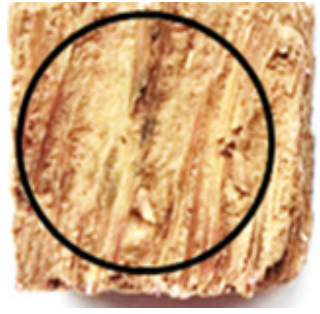

RS0

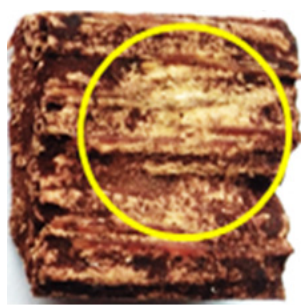

$\mathrm{RS} 2$
Keterangan :

RS0 $=$ Resin

$\mathrm{RS} 1=$ Resin $+4 \%$ Serbuk

RS2 $=$ Resin $+6 \%$ Serbuk

RS3 $=$ Resin $+8 \%$ Serbuk

Gambar 4. Visual kerusakan sampel akibat rayap kayu kering 


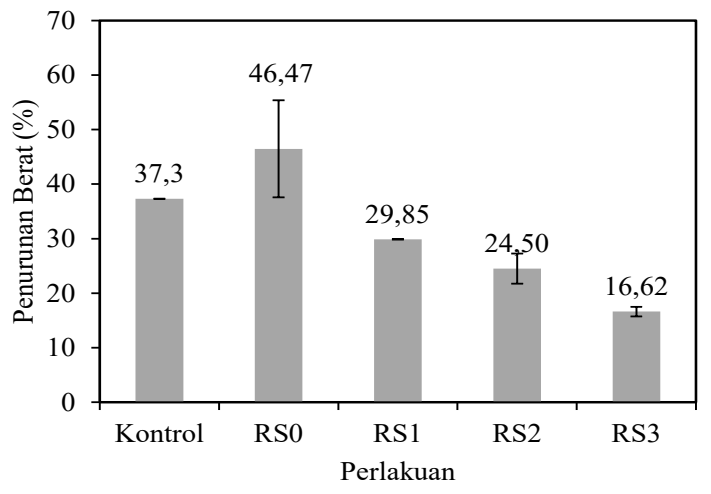

Keterangan : RS0 $=$ Resin; RS1 $=$ Resin $+4 \%$ Serbuk; RS2 $=$ Resin $+6 \%$ Serbuk; RS3 $=$ Resin $+8 \%$ Serbuk

Gambar 5. Penurunan berat rayap tanah formulasi resin pinus dan serbuk kayu surian

formulasi terhadap kontrol. Hasil uji DMRT menunjukkan tidak terdapat perbedaan yang signifikan antara formulasi RS1 dan RS2. Berdasarkan Tabel 3 dapat dilihat bahwa kontrol dan hampir semua formulasi resin-serbuk termasuk ke dalam kelas awet V kecuali formulasi RS3 memiliki kelas awet IV. Ketahanan terhadap serangan rayap tanah pada sampel yang diberi formulasi dibandingkan dengan kontrol memiliki peningkatan berkisar 20\%-55\%. Peningkatan ketahanan untuk formulasi RS1 20\%, RS2 34\%, dan RS3 55\%. Sampel RS0 memiliki perbedaan dibandingkan dengan formulasi lainnya yaitu penurunan ketahanan terhadap serangan rayap tanah sebesar $25 \%$.

Penurunan berat pada formulasi resin dan serbuk kayu surian terjadi akibat lapisan serbuk tersebut yang dikonsumsi oleh rayap tanah namun tidak sampai menyerang batang kelapa sawit yang diuji. Hal tersebut dapat ditunjukkan pada Gambar 6. Serbuk kayu surian yang digunakan memiliki kandungan selulosa dan sedikit zat ekstraktif. Kandungan zat ekstraktif yang sedikit diduga tidak akan meracuni rayap kayu kering, sehingga rayap masih dapat menyerang batang kelapa sawit yang diberikan. Hal ini sesuai dengan pernyataan Dungani et al. (2013) bahwa rayap menggunakan selulosa pada kayu sebagai sumber makanan.

Sampel RS0 memiliki penurunan berat yang paling tinggi dibandingkan formulasi resinserbuk lainnya. Hal ini diduga karena pada sampel tersebut tidak terdapat kandungan zat ekstraktif dari kayu surian. Kandungan zat ekstraktif pada kayu surian antara lain surenon, surenin, dan surenolakton yang memiliki fungsi insektisida, antifeedant (menghambat daya makan) bagi larva

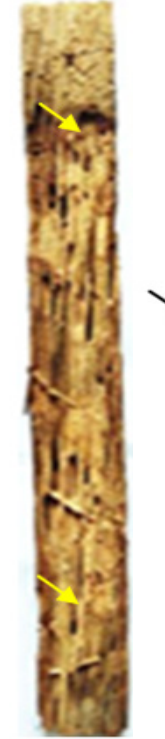

kontrol

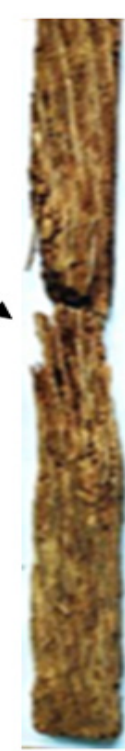

RS0

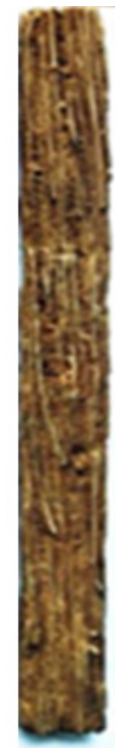

RS1

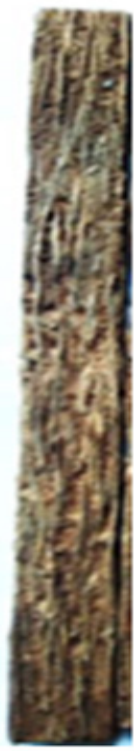

RS2
RS3

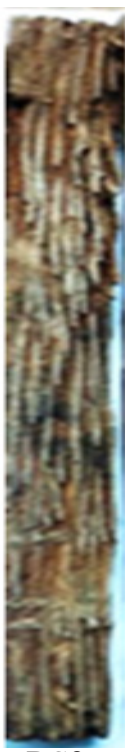

Keterangan :

RS0 $=$ Resin; RS1 = Resin $+4 \%$ Serbuk

RS2 $=$ Resin $+6 \%$ Serbuk; RS3 $=$ Resin $+8 \%$ Serbuk

Gambar 6. Visual kerusakan sampel akibat rayap tanah

serangga uji ulat sutera dan repellant (pengusir) serangga (Rakhman, 2012). Diduga zat ektraktif pada kayu surian yang berperan menjadi racun karena fungsi antifeedant dalam penelitian. Menurut Dungani et al. (2013), peran dari PF resin hanya meningkatkan kekerasan pada sampel yang terimpregnasi bukan sebagai racun. Selain itu, sesuai dengan pernyataan Dungani et al. (2013) bahwa formulasi batang sawit dengan bahan impregnasi PF resin termasuk kelas awet $\mathrm{V}$ dengan penurunan berat $24,85 \%$. Besarnya penurunan tidak sesuai dengan penelitian yang dilakukan oleh Dungani et al. (2013). Hal ini dikarenakan perbedaan konsentrasi dan jenis resin yang digunakan adalah $\mathrm{PF}$ resin dengan konsentrasi $15 \%$, sedangkan dalam penelitian ini menggunakan resin pinus tanpa diolah dengan konsentrasi $10 \%$.

Parameter lainnya dalam uji ketahanan rayap tanah adalah derajat kerusakan. Menururt Verinita (2012), derajat serangan rayap merupakan salah satu hal yang perlu diperhatikan untuk menilai ketahanan kayu terhadap serangan rayap tanah. Parameter ini mengkuantifikasikan derajat serangan dari visual sampel berdasarkan klasifikasi pada Tabel 4. Hasil dari klasifikasi dapat dilihat dari Tabel 5 dan Gambar 6. Tabel 5 menunjukkan bahwa derajat kerusakan paling 
Tabel 5. Derajat kerusakan rayap tanah formulasi resin pinus dan serbuk kayu surian

\begin{tabular}{lc}
\hline \multicolumn{1}{c}{ Formulasi } & Derajat Kerusakan \\
\hline Kontrol & 100 \\
Resin pinus & 100 \\
Resin-serbuk 4\% & 0 \\
Resin-serbuk 6\% & 0 \\
Resin-serbuk 8\% & 0 \\
\hline
\end{tabular}

tinggi adalah kontrol dan RS0. Formulasi RS1RS3 memiliki nilai yang sama.

Formulasi RS0 memiliki kesamaan nilai dengan kontrol karena sampel tersebut patah dan memiliki bagian yang hilang, sedangkan kontrol terdapat serangan pada permukaan yang cukup dalam dan meluas. Hal ini sesuai dengan penelitian yang dilakukan oleh Dungani et al. (2013) bahwa perlakuan batang kelapa sawit tanpa formulasi dan dengan formulasi PF resin memiliki derajat kerusakan yang cukup tinggi. Selain itu sesuai dengan pernyataan Verinita (2012), derajat kerusakan akan sebanding dengan kelas awet yang dimiliki kayu tersebut. Pada penelitian yang dilakukan oleh Dungani et al. (2013) pada batang kelapa sawit yang tidak melalui formulasi impregnasi dengan $\mathrm{PF}$ resin memiliki kelas awet $\mathrm{V}$.

Pada formulasi RS1-RS3 memiliki nilai yang sama dalam derajat kerusakan yaitu permukaan masih utuh atau tidak terlihat adanya serangan dari rayap tanah. Hal ini ada pengaruh dari serbuk kayu surian yang melapisi permukaan kayu kelapa sawit. Lapisan serbuk kayu surian pada permukaan yang diserang oleh rayap tanah terlebih dahulu tanpa menimbulkan kerusakan pada kayu kelapa sawit. Gambar 6 memperlihatkan adanya perbedaan warna pada beberapa bagian di sampel batang kelapa sawit. Bagian yang menjadi lebih terang menunjukkan bahwa rayap telah menyerang lapisan serbuk kayu surian yang terdapat dipermukaan sampel kayu kelapa sawit. Gambar 7 merupakan hasil pengamatan pengujian dengan menggunakan SEM (Scanning Electron Microscopy) antara perlakuan kontrol dan perlakuan impregnasi menggunakan resin pinus dan serbuk kayu Surian. Pada hasil pengamatan menunjukkan bahwa dengan perlakuan impregnasi dengan resin pinus dan serbuk kayu Surian hanya mempu menutupi

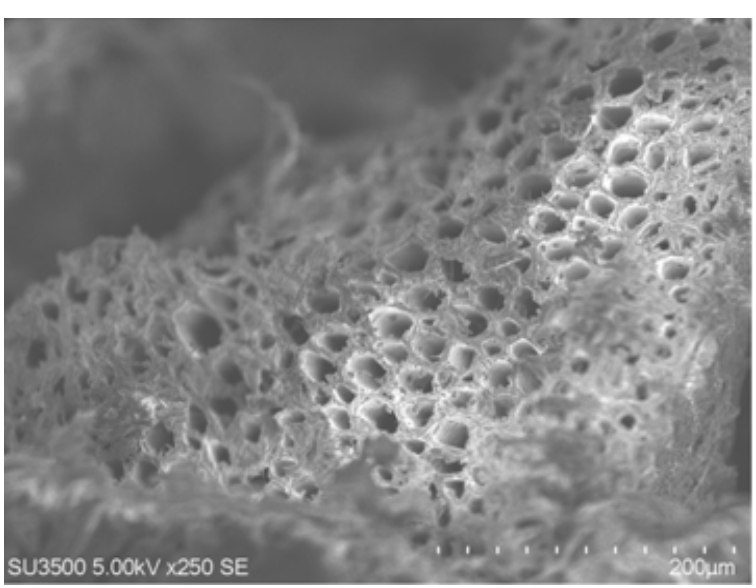

(a)

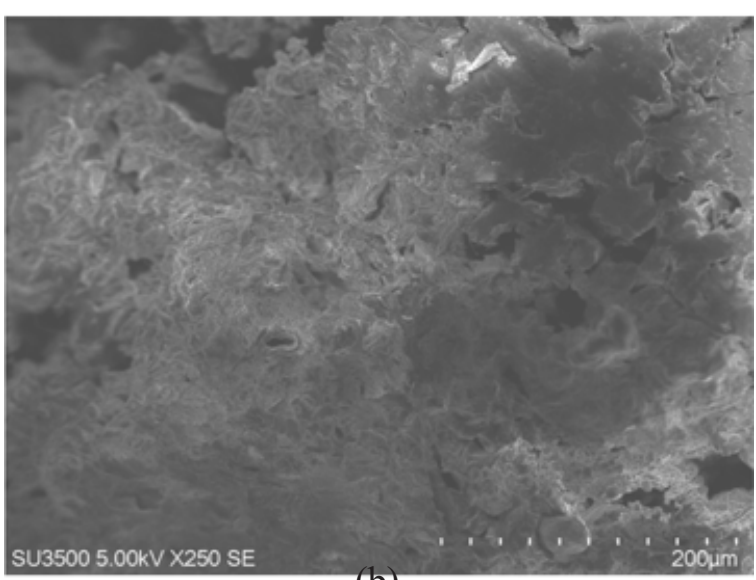

(b)

Gambar 7. Visual hasil pengujian SEM (a) kontrol dan (b) perlakuan impregnasi

bagian permukaan sampel dan tidak masuk ke dalam sel-sel batang kelapa sawit. Serbuk kayu surian yang digunakan memiliki kandungan selulosa dan sedikit zat ekstraktif. Kandungan zat ekstraktif yang sedikit diduga tidak akan meracuni rayap kayu kering sehingga rayap masih dapat menyerang batang kelapa sawit yang diberikan. Hal ini sesuai dengan pernyataan Dungani et al. (2013) bahwa rayap menggunakan selulosa pada kayu sebagai sumber makanan.

\section{Ketahanan Cuaca}

Penurunan berat merupakan salah satu parameter dari pengujian ketahanan cuaca (Islam et al., 2013). Gambar 8 menunjukkan bahwa formulasi RS0 memiliki penurunan berat yang paling rendah dibandingkan formulasi lainnya pada bulan ke-2. Formulasi lainnya dari paling rendah ke paling tinggi berturut-turut adalah RS2, RS1, RS3, dan kontrol. 
Berdasarkan hasil uji ANOVA $(\alpha=0,05)$ menunjukkan perbedaan yang signifikan dari formulasi terhadap kontrol. Hasil uji DMRT menunjukkan tidak terdapat perbedaan yang signifikan antara formulasi RS1 dan RS2 serta tidak terdapat perbedaan signifikan antara formulasi kontrol, RS1, dan RS3. Ketahanan terhadap cuaca pada sampel yang diberi formulasi dibandingkan dengan kontrol memiliki peningkatan berkisar 7\%-45\%. Peningkatan ketahanan untuk formulasi RS0 sebesar $45 \%$; RS1 11\%, RS2 20\%, dan RS3 7\%.

Kontrol memiliki penurunan berat yang paling tinggi dibandingkan dengan formulasi impregnasi ekstrak-resin. Hal ini sesuai dengan penelitian Islam et al. (2013) bahwa batang kelapa sawit tanpa formulasi memiliki penurunan berat paling tinggi dibandingkan formulasi impegnasi meskipun dilakukan pengujian selama 6 dan 12 bulan. Pada pengujian ketahanan terhadap cuaca dilakukan selama 3 bulan. Namun pada bulan ke-3 mengalami perubahan cuaca yang cukup ekstrem sehingga data yang digunakan hanya 2 bulan. Gambar 8 memiliki kecenderungan tren penurunan berat. Hal ini dikarenakan waktu pengujian merupakan bulan peralihan dari musim kemarau ke musim hujan namun intensitas curah hujan pada waktu pengujian bulan 1 dan 2 cukup jarang dan dapat dikatakan rendah sedangkan pada bulan ke-3 intensitas curah hujan meningkat drastis. Penambahan air akibat hujan akan mempengaruhi penurunan berat pada sampel. Hal ini sesuai dengan pernyataan Islam et al. (2013)

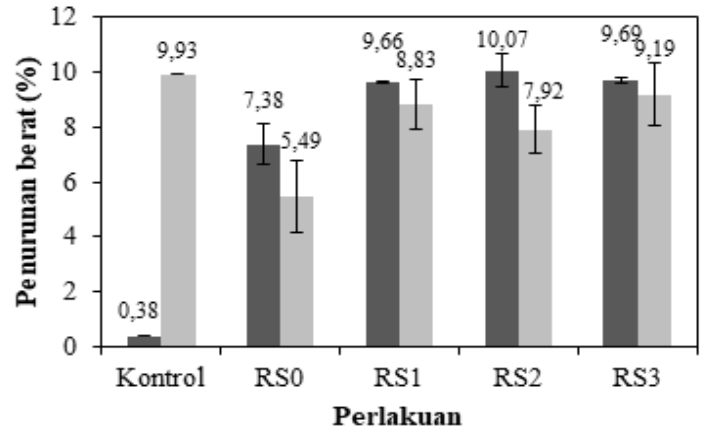

- Bulan 1 Bulan 2

Keterangan :

RS0 $=$ Resin; RS1 $=$ Resin $+4 \%$ Serbuk

RS2 $=$ Resin $+6 \%$ Serbuk; RS3 $=$ Resin $+8 \%$ Serbuk

Gambar 8.Penurunan berat ketahanan cuaca formulasi resin pinus dan serbuk kayu surian bahwa beberapa faktor yang dapat mempengaruhi penurunan berat dalam pencuacaan antara lain spesies dari kayu, kerapatan, mikroba, dan kondisi iklim seperti radiasi, hujan, angin.

Parameter lain menguji ketahanan terhadap cuaca adalah perubahan warna. Perubahan warna pada kayu dapat menunjukkan kualitas apabila digunakan untuk pemakaian luar ruangan (Krisdianto et al., 2018). Nilai total perubahan warna yang semakin besar menunjukkan perubahan warna yang semakin jauh. Apabila total perubahan warna memiliki nilai kecil, maka warna pada sampel masih bisa dipertahankan. Gambar 9 menunjukkan bahwa total perubahan warna yang paling rendah rendah secara keseluruhan adalah formulasi RS0. Formulasi lainnya dari total perubahan warna paling rendah ke paling tinggi berturut-turut adalah RS2, RS3, RS1, dan kontrol.

Total perubahan warna pada sampel setelah terpapar cuaca memiliki nilai di atas 5. Total perubahan warna memiliki nilai lebih dari 5 menunjukkan bahwa seseorang yang mangamati sampelsecara visual dapatmemberikan pernyataan bahwa sampel adalah dua warna yang berbeda dari sampel sebelum diuji (Mokrzycki and Tatol, 2011). Selain itu, hasil penelitian mengungkapkan bahwa perubahan warna dengan nilai 0,22-2,91 termasuk ke dalam kategori perubahan warna sedikit hingga sedang (Krisdianto, Satiti and Supriadi, 2018). Hal ini menunjukkan bahwa perubahan warna yang dilakukan dalam penelitian ini termasuk ke dalam perubahan warna yang

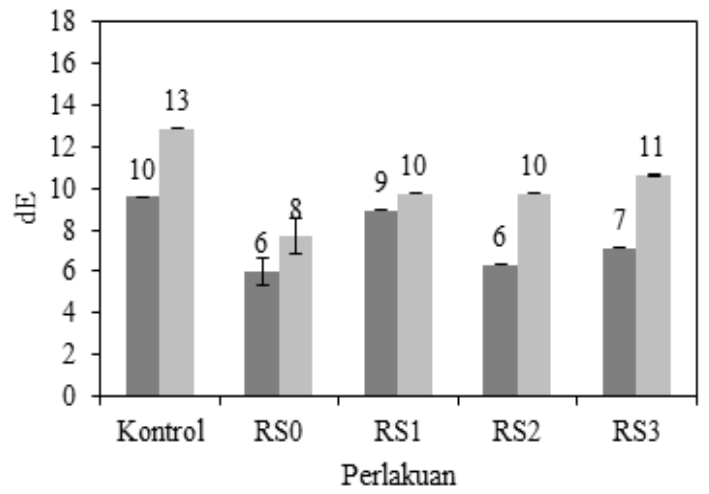

Keterangan :

RS0 $=$ Resin; RS1 $=$ Resin $+4 \%$ Serbuk

RS2 $=$ Resin $+6 \%$ Serbuk; RS3 $=$ Resin $+8 \%$ Serbuk

Gambar 9. Perubahan warna formulasi resin pinus dan serbuk kayu surian 
besar. Perubahan warna yang terjadi pada sampel dapat diakibatkan sampel terpapar oleh sinar UV dalam pengujian ketahanan cuaca. Hal ini sesuai dengan pernyataan Islam et al. (2013) bahwa sinar UV dapat mengubah struktur kimia pada kayu sehingga menyebabkan perubahan warna, warna memudar, permukaan retak, struktur mikro kayu rusak, dan kekuatan kayu melemah.

Gambar 10 menunjukkan bahwa pada formulasi resin-serbuk memiliki kecenderungan memudar dan mendekati abu-abu. Perubahan warna kayu menjadi abu-abu hingga abu pucat akibat terjadinya pencucian warna dipermukaan kayu (Krisdianto, Satiti and Supriadi, 2018). Proses pencucian warna merupakan efek samping dari proses delignifikasi di permukaan kayu akibat perubahan suhu dan kelembapan serta pencahayaan sinar matahari yang berulang. Proses delignifikasi terjadi karena sinar UV masuk ke dalam kayu karena pada kayu memiliki struktur selulosa yang terdiri dari gugus grup hidroksil chromophoric aromatic yang memiliki kemampuan untuk menyerap cahaya (Temiz et al., 2007). Dalam penelitian ini diduga bahwa serbuk kayu surian pada formulasi resin-serbuk memiliki andil yang cukup besar dalam perubahan warna pada sampel yang mendekati abu-abu. Hal ini dikarenakan serbuk kayu surian yang memiliki kandungan selulosa, memberi lapisan pada permukaan sampel batang kelapa sawit. Pelepasan kelompok karbonil dari keton, aldehid, dan quinine akibat perubahan lignin dapat menyebabkan perubahan warna dari

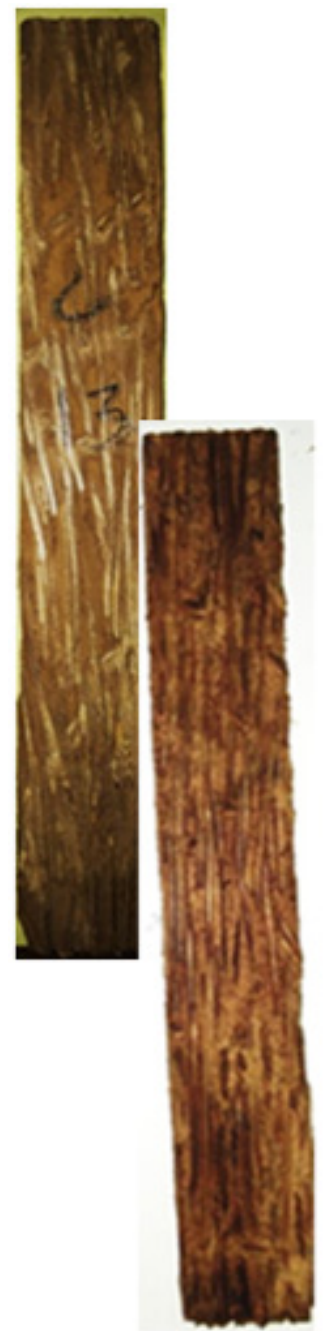

kontrol

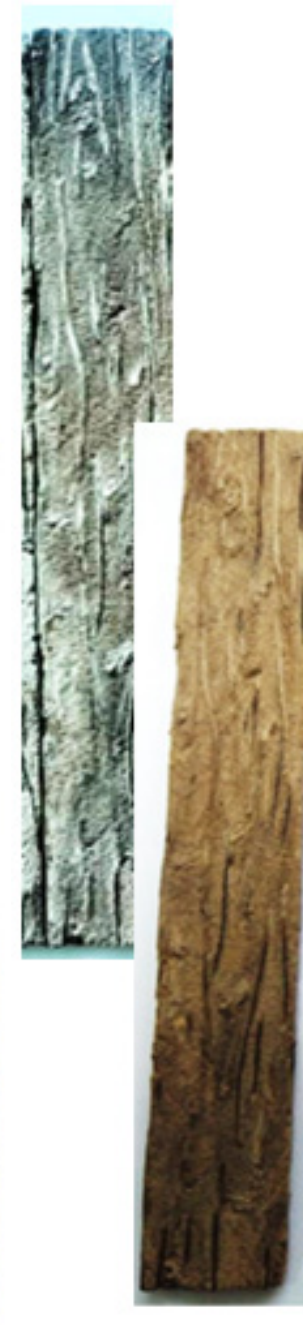

RS0

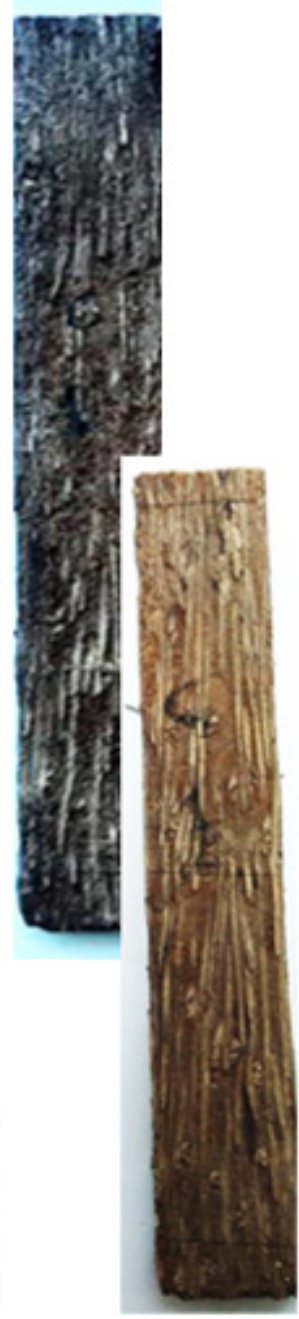

RS1

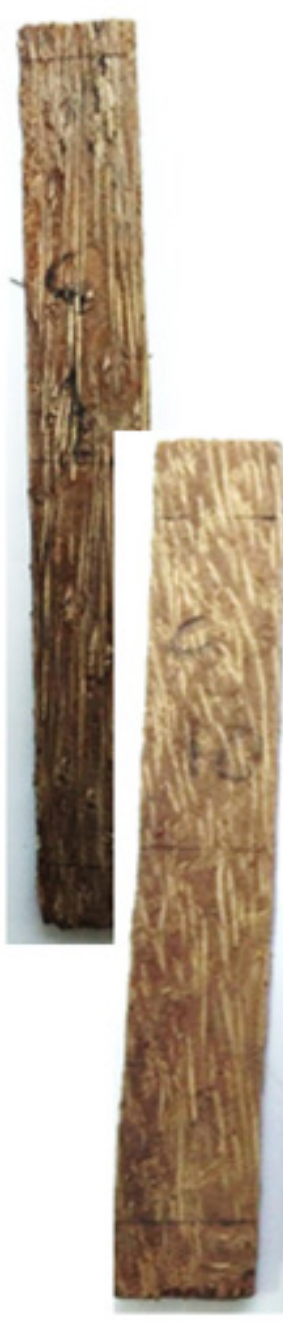

RS2

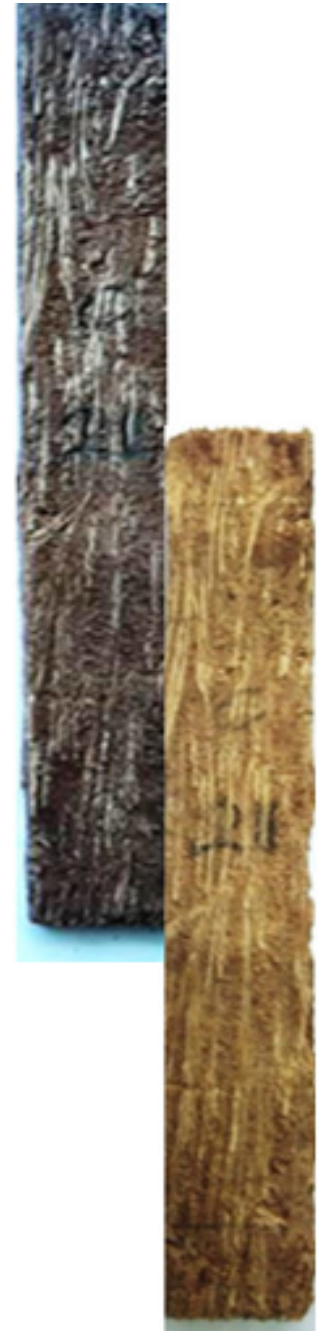

RS3

Keterangan :

RS0 $=$ Resin; RS1 $=$ Resin $+4 \%$ Serbuk; RS2 $=$ Resin $+6 \%$ Serbuk; RS3 $=$ Resin $+8 \%$ Serbuk

Gambar 10. Perubahan warna sampel akibat cuaca 
coklat/kuning menjadi abu-abu selama pengujian ketahanan cuaca (Krisdianto, Satiti and Supriadi, 2018).

Parameter lainnya pada uji ketahanan cuaca adalah FT-IR. Parameter FT-IR membuktikkan adanya perubahan struktur pada batang kelapa sawit terimpregnasi setelah uji ketahanan cuaca. Hasil pengujian FT-IR pada kontrol dan formulasi ekstrak-resin cenderung memiliki pola yang sama seperti pada Gambar 11. Apabila pengujian ketahanan cuaca dilanjutkan lebih lama, diduga akan menunjukkan perubahan pola yang terilhat lebih kontras.

Tabel 6 menunjukkan pergeseran pita serapan pada daerah ikatan yang sama. Selain itu terdapat pita serapan yang muncul pada bulan 1 pada kontrol dan formulasi RS0 lalu hilang pada bulan berikutnya. Terjadinya pergeseran dan kemunculan pita serapan baru merupakan ciri dari perubahan pada gugus fungsi. Perubahan pada gugus kimia pada kayu akibat reaksi kimia yang terjadi selama sampel terpapar oleh sinar UV selama pengujian ketahanan cuaca. Hal ini seusai dengan pernyataan Islam et al. (2013) bahwa sinar UV dapat mengubah struktur kimia pada kayu sehingga menyebabkan perubahan warna, warna memudar, permukaan retak, struktur mikro kayu rusak, dan kekuatan kayu melemah sehingga parameter pengujian FT-IR menjadi pendukung dari perubahan warna akibat ketahanan terhadap cuaca. Selain itu, perubahan pada spektrum FT-IR menunjukkan adanya reaksi kimia yang terjadi selama kayu terpapar oleh cuaca adalah dehidrasi, hidrolisis, oksidasi, dekarboksilasi, dan transglikosilasi.

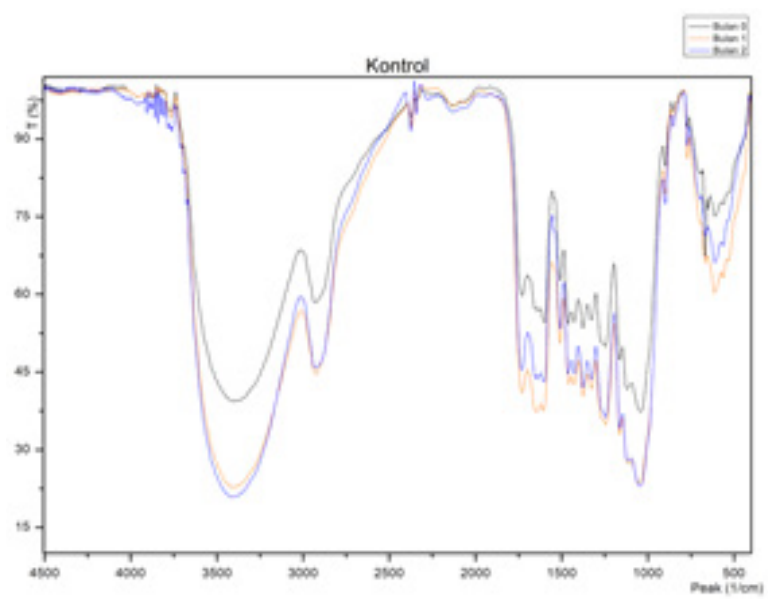

(a)

\section{Prospek Penggunaan}

Berdasarkan hasil penelitian dapat dilihat bahwa pemberian formulasi resin-serbuk dapat meningkatkan ketahanan terhadap rayap kayu kering, rayap tanah, dan cuaca. Ketahanan batang kelapa sawit terhadap serangan rayap kayu kering meningkat sekitar $68 \%-84 \%$ pada formulasi resin-serbuk. Kelas awet mengalami peningkatan dari sebelumnya kelas awet IV menjadi kelas awet I-II setelah diberi formulasi impregnasi. Selain itu, ketahanan batang kelapa sawit terhadap rayap tanah meningkat sekitar 20\%-55\% pada formulasi resin-serbuk. Kelas awet mengalami peningkatan menjadi kelas awet IV pada formulasi resinserbuk $8 \%$. Maka peningkatan secara keseluruhan ketahanan batang sawit terimpregnasi terhadap rayap kayu kering dan rayap tanah adalah $20 \%$ $84 \%$ untuk formulasi resin-serbuk dengan kelas awet termasuk ke dalam kelas awet I-IV.

Pada ketahanan terhadap cuaca, peningkatan ketahanan pada parameter penurunan berat berkisar 7\%-45\% untuk formulasi resin-serbuk. Hal tersebut menunjukkan peningkatan ketahanan termasuk rendah karena memiliki nilai dibawah $50 \%$. Selain itu, pada parameter perubahan warna dan FT-IR menunjukkan bahwa pemberian impregnasi tidak menunjukkan perbedaan karena selama pengujian masih terlihat memiliki pola pergeseran dan perubahan yang sama dengan kontrol.

Berdasarkan uraian di atas, dapat dilihat bahwa formulasi impregnasi dengan pemberian impregnan berbeda dapat digunakan sesuai kebutuhan salah satunya furnitur. Furnitur

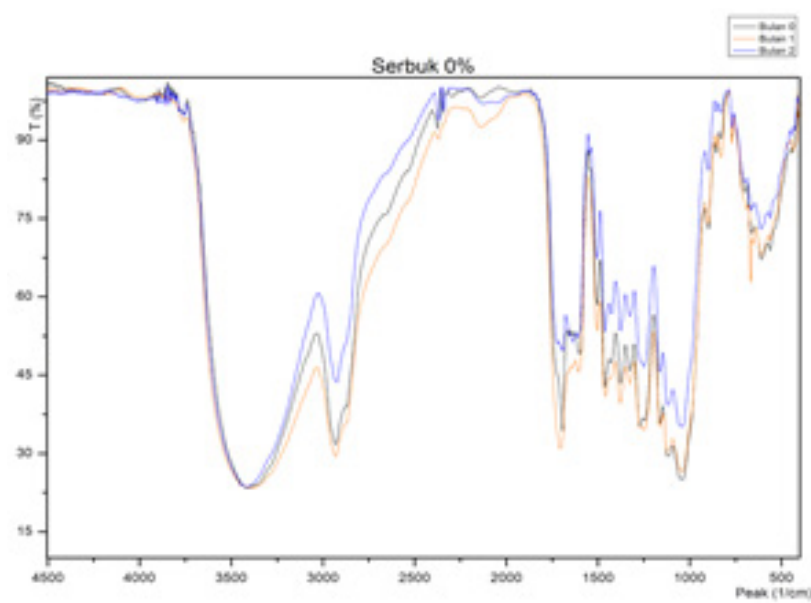

(b)

Gambar 11. FT-IR kontrol (a) dan formulasi resin pinus dan serbuk kayu surian 0\% (b) 
Tabel 6. FT-IR kontrol dan RS0

\begin{tabular}{|c|c|c|c|c|c|c|c|}
\hline & Kontrol & & & RS0 & & \multirow{3}{*}{ Ikatan } & \multirow{3}{*}{ Sumber } \\
\hline Bulan 0 & Bulan 1 & Bulan 2 & Bulan 0 & Bulan 1 & Bulan 2 & & \\
\hline $\begin{array}{l}\text { peak } \\
(1 / \mathrm{cm})\end{array}$ & $\begin{array}{l}\text { peak } \\
(1 / \mathrm{cm})\end{array}$ & $\begin{array}{c}\text { peak } \\
(1 / \mathrm{cm})\end{array}$ & $\begin{array}{l}\text { peak } \\
(1 / \mathrm{cm})\end{array}$ & $\begin{array}{l}\text { peak } \\
(1 / \mathrm{cm})\end{array}$ & $\begin{array}{l}\text { peak } \\
(1 / \mathrm{cm})\end{array}$ & & \\
\hline 3410 & 3406 & 3410 & 3412 & 3410 & 3426 & Regangan $\mathrm{OH}$ & $\begin{array}{l}\text { Sutrisno et al. (2014) dan } \\
\text { Dachriyanus (2004) }\end{array}$ \\
\hline 2934 & 2922 & 2922 & $\begin{array}{l}2932- \\
2872\end{array}$ & 2930 & 2924 & Regangan $\mathrm{CH}$ & $\begin{array}{l}\text { Sutrisno et al. (2014) dan } \\
\text { Dachriyanus (2004) }\end{array}$ \\
\hline $\begin{array}{l}1728- \\
1655\end{array}$ & 1728 & 1730 & 1694 & 1707 & 1694 & Regang $\mathrm{C}=\mathrm{O}$ & UPS (2020) \\
\hline $\begin{array}{l}1597- \\
1506\end{array}$ & $\begin{array}{l}1643- \\
1508\end{array}$ & $\begin{array}{l}1641- \\
1506\end{array}$ & $\begin{array}{l}1597- \\
1504\end{array}$ & $\begin{array}{l}1607- \\
1504\end{array}$ & $\begin{array}{l}1641- \\
1504\end{array}$ & $\begin{array}{l}\text { Regang } \mathrm{C}=\mathrm{C} \text { (aro- } \\
\text { matik dan alifatik) }\end{array}$ & Dachriyanus (2004) \\
\hline $\begin{array}{l}1462- \\
1327\end{array}$ & $\begin{array}{l}1458- \\
1327\end{array}$ & $\begin{array}{l}1462- \\
1327\end{array}$ & $\begin{array}{l}1462- \\
1273\end{array}$ & $\begin{array}{l}1458- \\
1327\end{array}$ & $\begin{array}{l}1462- \\
1327\end{array}$ & Kibasan C-H & $\begin{array}{l}\text { Sutrisno et al.(2014) dan } \\
\text { Dachriyanus (2004) }\end{array}$ \\
\hline 1246 & 1246 & 1246 & 1246 & 1246 & 1248 & $\begin{array}{l}\text { Regangan } \mathrm{C}=\mathrm{O} \\
\text { lignin }\end{array}$ & Owolabi et al. (2016) \\
\hline 1163 & 1163 & 1163 & 1163 & 1163 & 1163 & $\begin{array}{l}\text { Kibasan } \mathrm{CH}_{2} \text { selulo- } \\
\text { sa amorf }\end{array}$ & Owolabi et al. (2016) \\
\hline 1121 & 1109 & 1111 & 1123 & 1125 & 1123 & Regangan C-O & UPS (2020) \\
\hline 1040 & 1053 & 1051 & 1038 & 1036 & 1053 & Glikosidik C-O-C & Sutrisno et al. (2015) \\
\hline 899 & 899 & 897 & 897 & 899 & 899 & $\begin{array}{l}\text { Kibasan CH2 selulo- } \\
\text { sa amorf }\end{array}$ & Owolabi et al. (2016) \\
\hline- & 853 & - & - & 831 & - & $\begin{array}{l}\text { Vibrasi C-O-C pada } \\
\text { bidang, simetri }\end{array}$ & Sutrisno et al. (2014) \\
\hline $667-611$ & $770-613$ & $\begin{array}{c}770- \\
611\end{array}$ & $\begin{array}{l}770- \\
608\end{array}$ & $\begin{array}{l}770- \\
611\end{array}$ & $\begin{array}{l}770- \\
613\end{array}$ & $\begin{array}{l}\text { Vibrasi C-OH luar } \\
\text { bidang }\end{array}$ & Sutrisno et al. (2014) \\
\hline
\end{tabular}

memiliki syarat khusus yang mengacu SNI 0608:2017 - Kayu untuk furnitur (persyaratan karakteristik). Kebutuhan untuk dijadikan furnitur eksterior memiliki syarat kelas awet I-II dan kelas awet III-V (kayu yang sudah diawetkan menjadi kelas I-II) sedangkan untuk interior memiliki syarat kelas awet III-V. Berdasarkan hasil penelitian mengenai keawetan (ketahanan rayap kayu kering dan rayap tanah), batang kelapa sawit yang telah diimpregnasi termasuk ke dalam fungsi furnitur eksterior dan interior. Namun hasil uji ketahanan cuaca tidak mendukung batang kelapa sawit yang telah diimpregnasi untuk penggunaan eksterior. Oleh karena itu, hasil dari penelitian ini dapat digunakan untuk furnitur dengan fungsi interior. Hal ini hanya dilihat dari aspek keawetan saja.

\section{Kesimpulan}

Secara keseluruhan dari penelitian menunjukkan kecenderungan peningkatan ketahanan kayu kelapa sawit terimpregnasi terhadap rayap kayu kering dan rayap tanah serta ketahanan cuaca dibandingkan dengan kontrol. Berdasarkan hasil penelitian dengan formulasi impregnan RS0, RS1, RS2, RS3, serta kontrol terhadap ketahanan rayap kayu kering, rayap tanah, dan cuaca, dapat disimpulkan bahwa kayu kelapa sawit terimpregnasi dengan bahan impregnan RS3 merupakan formulasi yang paling optimum terhadap rayap kayu kering dan rayap tanah dengan kelas awet IIIV. Peningkatan kualitas RS3 berkisar 55-75\%. Berdasarkan ketahanan cuaca, batang kelapa 
sawit terimpregnasi dengan impregnan formulasi RS0 merupakan yang paling optimum.dari parameter penurunan berat dan perubahan warna. Peningkatan kualitas RS0 sebesar 45\%.

\section{Ucapan Terima Kasih}

Penulis mengucapkan terima kasih kepada Lembaga Penelitian dan Pengabdian Masyarakat (LPPM) Institut Teknologi Bandung pada program Riset ITB 2021 yang telah memberikan Hibah Penelitian untuk penelitian ini. Penulis juga mengucapkan terima kasih kepada Dr. Endah Sulistyawati selaku Dekan Sekolah Ilmu dan Teknologi Hayati ITB yang telah memberikan fasilitas yang diperlukan untuk mempersiapkan bagian dari penelitian ini.

\section{Daftar Pustaka}

Balfas, J. (2003) 'Potensi kayu sawit sebagai alternatif bahan baku industri perkayuan', in Seminar Nasional Himpunan Alumni-IPB dan Hapka Fakultas Kehutanan IPB Wilayah Regional Sumatera. Medan.

Basri, E. and Balfas, J. (2014) 'Impregnasi ekstrak jati dan resin pada kayu jati cepat tumbuh dan karet', Jurnal Penelitian Hasil Hutan, 32(4), pp. 283-296. doi: 10.20886/ jphh.2014.32.4.283-296.

Dachriyanus, D. (2004) Analisis struktur senyawa organik secara spektroskopi. Lembaga Pengembangan Teknologi Informasi dan Komunikasi (LPTIK) Universitas Andalas.

Direktorat Jenderal Perkebunan (2020) Luas areal kelapa sawit menurut provinsi di Indonesia, 2017-2021. Available at: www. pertanian.go.id. (Accessed December 2021).

Dungani, R., Islam, M. N., Khalil, H. P. S. A., Hartati, S., Abdullah, C. K., Dewi, M. and Hadiyane, A. (2013) 'Termite resistance study of oil palm trunk lumber (OPTL) impregnated with oil palm shell meal and phenol-formaldehyde resin', BioResources, 8(4), pp. 4937-4950. doi: 10.15376/ biores.8.4.4937-4950.

Dungani, R. (2015) Ancaman serangan rayap di kampus ITB Jatinangor. Available at: https:// klinikkayu.sith.itb.ac.id/sites/klinikkayu/ files/upload/Poster-Rayap-3-2015.pdf. (Accessed May 2020)

Erwinsyah, E. (2008) Improvement of oil palm trunk properties using bioresin. Technische Universität Dresden, German.
Hartono, R. and Erwinsyah, E. (2018) 'Distribusi kerapatan dan kurva stress-strain pada batang kelapa sawit', Talenta Conference Series: Agricultural and Natural Resources (ANR), 1(1), pp. 124-130. doi: 10.32734/anr.vli1.131.

Islam, M. N., Dungani, R., Abdul Khalil, H., Alwani, M. S., Nadirah, W. W. and Fizree, H. M. (2013) 'Natural weathering studies of oil palm trunk lumber (OPTL) green polymer composites enhanced with oil palm shell (OPS) nanoparticles', SpringerPlus, 2(592), pp. 1-12. doi: 10.1186/2193-1801-2-592.

Kementerian Koordinator Bidang Perekonomian (2021) Program Peremajaan Sawit Rakyat Mendorong Penyerapan Tenaga kerja dan Menciptakan Multiplier Effect. Available at: https://ekon.go.id/publikasi/detail/3312/ program-peremajaan-sawit-rakyatmendorong-penyerapan-tenaga-kerja-danmenciptakan-multiplier-effect.

Kementerian Pertanian (2020) Luas areal kelapa sawit menurut provinsi di Indonesia, 20152019. Available at: www.pertanian.go.id/ home/index.php? show=repo\&fileNum=229. (Accessed April 2020).

Krisdianto, K., Satiti, E. R. and Supriadi, A. (2018) 'Perubahan warna dan lapisan finishing lima jenis kayu akibat pencuacaan', Jurnal Penelitian Hasil Hutan, 36(3), pp. 205-210. doi: 10.20886/jphh.2018.36.3.205-218.

Mokrzycki, W. and Tatol, M. (2011) 'Color difference $\Delta \mathrm{E}$ - A survey', Machine Graphics and Vision, 20, pp. 383-411.

Mulyono, A. (2000) Kajian sifat pemesinan kayu kelapa sawit (Elaeis quineensis jacq.) terkompregnasi sebagai bahan bangunan dan perabotan rumah tangga. IPB (Bogor Agricultural University).

Nurfajriani, N. (2015) Kompreganasi reaktif in-situ kayu kelapa sawit dengan resin damar (Agathis dammara) dan poliuretan termodifikasi. Universitas Sumatera Utara.

Owolabi, A. W. T., Arniza, G., Wan Daud, W. and Alkharkhi, A. F. M. (2016) 'Effect of alkaline peroxide pre-treatment on microfibrillated cellulose from oil palm fronds rachis amenable for pulp and paper and biocomposite production', BioResources, 11(2), pp. 3013-3026. doi: 10.15376/ biores.11.2.3013-3026.

Rakhman, A. N. (2012) Beberapa sifat dasar kayu Surian (Toona sinensis) asal Kabupaten Indramayu, Jawa Barat. Bogor Agricultural University (IPB).

Sukatik, S. and Yunida, Y. (2006) 'Impregnasi kayu kelapa sawit (KKS) dengan resin getah Pinus merkusii berbasis air', Rekayasa Sipil 2(1), pp. 1-8. 
Sutrisno, S., Syamsudin, T. S., Alamsyah, E. M. and Purwasasmi, B. S. (2014) 'Synthesis of bio-based nanomaterial from Surian (Toona sinensis Roem) wood bark using conventional balls milling method and its characterization', Journal of Biological Sciences, 14(3), pp. 204-212. doi: 10.3923/ jbs.2014.204.212.

Sutrisno, S., Syamsudin, T. S., Alamsyah, E. M. and Sunendar, B. (2015) 'Synthesis and Characterization of Bio-based Nanomaterials from Jabon (Anthocephalus cadamba (Roxb.) Miq) Wood Bark: an Organic Waste Material from Community Forest', Journal of Mathematical and Fundamental Sciences, 47(2), pp. 205-218. doi: 10.5614/j.math. fund.sci.2015.47.2.7.
Temiz, A., Terziev, N., Eikenes, M. and Hafren, J. (2007) 'Effect of accelerated weathering on surface chemistry of modified wood', Applied Surface Science, 253(12), pp. 53555362. doi: 10.1016/j.apsusc.2006.12.005.

UPS (2020) Ir-frequencies, University of Puget Sound. Available at: https:// www2.pugetsound.edu/academics/ academic-resources/collins-memoriallibrary/\#carbonylIR.

Verinita, L. (2012) Ketahanan tiga jenis kayu hutan rakyat terhadap serangan rayap tanah. Institut Pertanian Bogor. 